\title{
MAPPING AND EVALUATION OF REFERENCE EVAPOTRANSPIRATION METHODS UNDER ARID CONDITIONS
}

\author{
Mahmoud M. Ali* \\ Ali G. Mahmoud**
}

\section{ABSTRACT}

Reference evapotranspiration (ETo) is a vital factor in water resources managing and planning. Various estimation methods have been developed for different climatic regions and according to the available data. Therefore, the reliability of such methods depends upon climatic conditions. The present investigation evaluates four temperature based methods: FAO Blaney-Criddle (BC), Turc, Jensen-Haise (JH) and Hargreaves $(H G)$, and two radiation based methods: FAO-radiation (FAO-rad) and Priestley-Taylor (PT) in comparison with the FAO-PM method under arid conditions of Libya. In order to select the best ETo method, the percentage error of estimate (PE), the root mean square error (RMSE), and mean bias error (MBE) were calculated. The obtained ETo values (FAO-PM and the average of best-estimated monthly ETo) were utilized to generate spatial distribution maps of ETo with the aid of Kriging technique. Statistical analysis of the obtained results revealed that, Turc equation fitted well for the northern part of the study area. Which include Nalut, Zuara, Mosrata, Sirt, Shahat, Derna, Tubruk, Hon, Galo and Gagbub. While for southern zone, HG equation performed better for Opari and Tazirbu, BC equation for Kufra and Ghadames, FAO-Rad equation for Sebha; and JH equation for Ghat.

Keywords: Reference Evapotranspiration; FAO-PM; Arid conditions; Kriging

\section{INTRODUCTION}

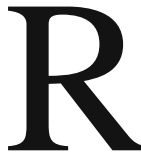
eference evapotranspiration (ETo) is the synchronized transpiration and evaporation processes in a soil-plant system (Tabari et al., 2011). ETo has a great importance in irrigation scheduling, together with climatological and hydrological studies (Sentelhas et al., 2010).

\footnotetext{
* Agricultural Engineering Department, Faculty of Agriculture, Fayoum University. ** Soil and Water Department, Faculty of Agriculture, Fayoum University.
} 
Several methods have been developed to estimate ETo and they vary in required climatic-data. For many regions and climatic conditions, the Penman-Monteith method (P-M) has proved to be the best method and gives consistent ETo values (Allen et al. 2005, 2006). Thus, it is widely applied in various fields, among which are agronomy and irrigation management (Alexandris et al. 2006; Landeras et al, 2008; Du, et al., 2010; Hassanli, et al., 2010; Sentelhas et al. 2010).

In case of limited data required for P-M method, especially in the developing countries, significant attention has been paid to the evaluation of simple ETo methods and their application. The FAO-Penman-Monteith method (P-M) has proved of superior performance (Jensen et al. 1990; Allen et al. 1998; Abdelhadi et al., 2000; Hargreaves and Allen 2003; LopezUrrea et al., 2006; Gavilan et al., 2007; Trajkovic and Kolakovic, 2009; Martinez Thepadia, 2010). Therefore, the P-M method was used in this study to evaluate the reliability of the other ETo estimating methods. P-M method uses temperature, relative humidity, wind speed and solar radiation/sunshine to estimate ETo. The main limitation of the P-M method is the necessity for various weather data parameters (i.e., air temperature, humidity, wind speed, and solar radiation) which might be not available. Such limitation may exist particularly in developing countries (Droogers and Allen, 2002; Gocic and Trajkovic 2010; Maeda et al. 2011; Tabari et al. 2011). This is because of the difficulties in setting-up of weather stations, their maintenance and expenses (Sentelhas et al. 2010). One way to overcome such problem, is to utilize the ETo equations that require fewer meteorological parameters, several methods are developed to estimate ETo. But the simpler methods might give inconsistent ETo values (George et al., 2002; Xu and Singh, 2002; Lu et al., 2005; Temesgen et al., 2005; Nandagiri and Kovoor, 2006). Therefore, simpler equations must be evaluated against the P-M method or lysimetric measurements in order to find out the most suitable ETo method for each region where weather data are inadequate to apply the PM method (Trajkovic and Kolakovic, 2009).

The present work was carried out to assess the performance of six simple ETo methods that require less readily available data against the P-M 
method in order to select the most suitable method to estimate ETo values in Libya. Maps representing the distribution of the ETo values and their relation to elevation above sea level is performed.

\section{MATERIALS AND METHODS}

\section{a) Location and climatic parameters of the study area:}

The present investigation was carried out in the country of Libya (area of $1,760,000 \mathrm{~km}^{2}$ ) with a Mediterranean Coastline of nearly 1,800 kilometers. Seventeen meteorological stations were selected to represent the different regions of the country. Figure (1) shows the distribution of chosen stations (as a point map); the geographic characteristics of these stations are presented in Table (1).

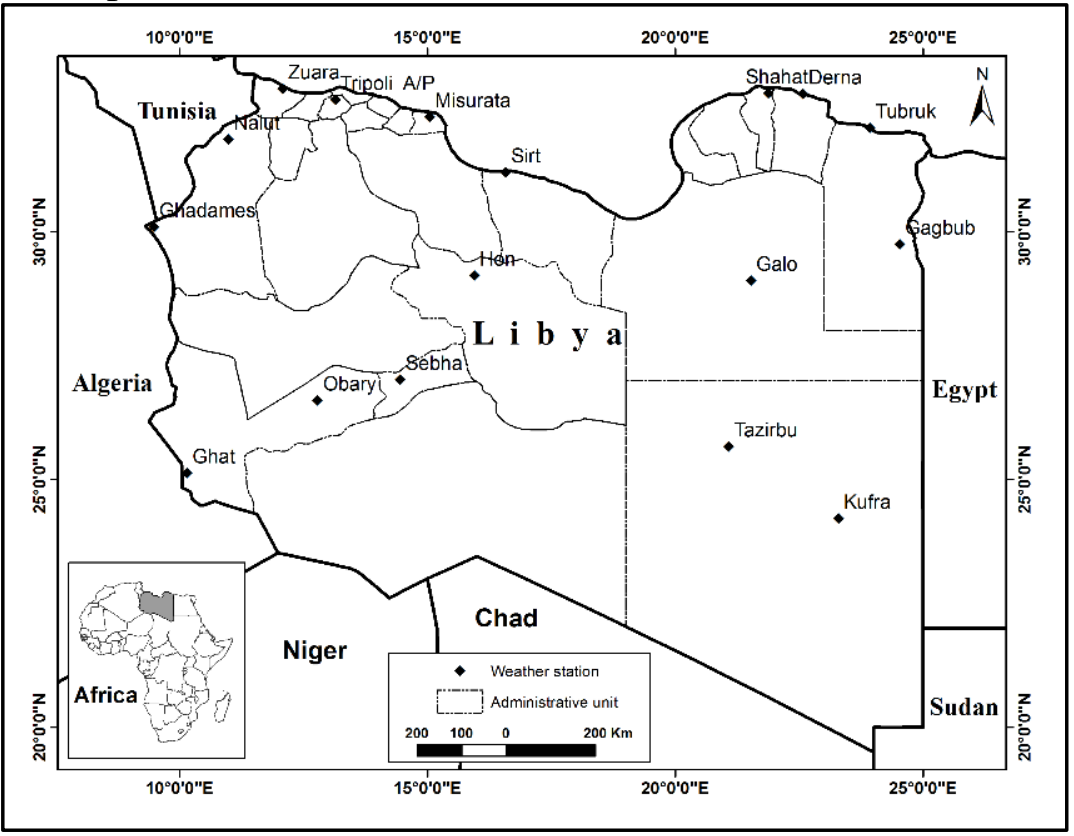

Fig. (1): Study area and location of the weather stations

The climatic data of the study area showed that the monthly meantemperature varies from 12 to $30{ }^{\circ} \mathrm{C}$. While the relative humidity ranges between 15 to $60 \%$, Figure (2).

\section{b) Reference evapotranspiration (ETo) calculations:}

Seven different methods were used to estimate (ETo) at the studied seventeen locations. Applied methods were classified into their major methods as follows; a) one combination method [1- FAO 56-PenmanMonteith (PM)], b) four temperature methods [2- FAO Blaney-Criddle 
(BC), 3- Turc, 4- Jensen-Haise (JH) and 5- Hargreaves (HG)]; c) two radiation methods [(6- FAO radiation (FAO-Rad), and 7- Priestley Taylor (PT)].

Table 1: Location, elevation, latitude and longitude of the studied meteorological stations.

\begin{tabular}{cccccc}
\hline Station Name & $\begin{array}{c}\text { Elevation (m) } \\
\text { (Above sea level) }\end{array}$ & $\begin{array}{c}\text { Latitude } \\
\text { (Degrees } \\
\text { and Minutes) }\end{array}$ & \multicolumn{2}{c}{$\begin{array}{c}\text { Longitude } \\
\text { (Degrees } \\
\text { and Minutes) }\end{array}$} \\
\hline Nalut & 621 & $31^{\circ}$ & $52^{\prime}$ & $10^{\circ}$ & $59^{\prime}$ \\
Zoara & 3 & $32^{\circ}$ & $53^{\prime}$ & $12^{\circ}$ & $05^{\prime}$ \\
Tripoli & 81 & $32^{\circ}$ & $40^{\prime}$ & $13^{\circ}$ & $09^{\prime}$ \\
Mosrata & 32 & $32^{\circ}$ & $19^{\prime}$ & $15^{\circ}$ & $03^{\prime}$ \\
Sirt & 13 & $31^{\circ}$ & $12^{\prime}$ & $16^{\circ}$ & $35^{\prime}$ \\
Shahat & 649 & $32^{\circ}$ & $48^{\prime}$ & $21^{\circ}$ & $53^{\prime}$ \\
Derna & 26 & $32^{\circ}$ & $47^{\prime}$ & $22^{\circ}$ & $35^{\prime}$ \\
Tubruk & 50 & $32^{\circ}$ & $06^{\prime}$ & $23^{\circ}$ & $56^{\prime}$ \\
Ghadames & 346 & $30^{\circ}$ & $06^{\prime}$ & $09^{\circ}$ & $29^{\prime}$ \\
Sebha & 432 & $27^{\circ}$ & $01^{\prime}$ & $14^{\circ}$ & $27^{\prime}$ \\
Hon & 263 & $29^{\circ}$ & $07^{\prime}$ & $15^{\circ}$ & $57^{\prime}$ \\
Galo & 45 & $29^{\circ}$ & $01^{\prime}$ & $21^{\circ}$ & $32^{\prime}$ \\
Gagbub & 01 & $29^{\circ}$ & $45^{\prime}$ & $24^{\circ}$ & $32^{\prime}$ \\
Opari & 463 & $26^{\circ}$ & $36^{\prime}$ & $12^{\circ}$ & $47^{\prime}$ \\
Ghat & 692 & $25^{\circ}$ & $08^{\circ}$ & $10^{\circ}$ & $09^{\prime}$ \\
Tazirbu & 261 & $25^{\circ}$ & $40^{\circ}$ & $21^{\circ}$ & $05^{\prime}$ \\
Kufra & 436 & $24^{\circ}$ & $13^{\circ}$ & $23^{\circ}$ & $18^{\prime}$ \\
\hline
\end{tabular}

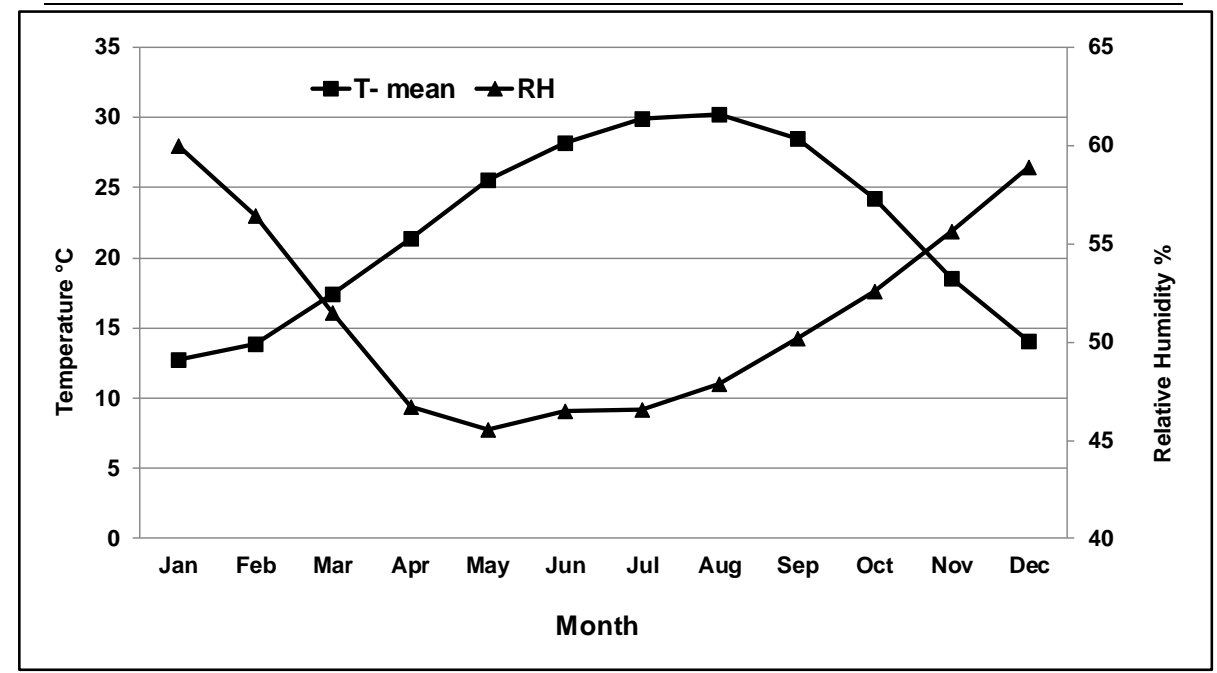

Fig. (2): Average mean temperature and relative humidity in Libya 
The combination methods for ETo estimation depends upon recorded temperature, relative humidity, wind speed and solar radiation or sunshine. If such data are available, the P-M method ranked the first to estimate (ETo) between all other combination methods. As mentioned above, FAO 56-PM method was selected in this study to be the reference method. The equations of each method are presented in Table (2).

Table 2: Methods and equations used to estimate reference evapotranspiration (ETo)

Method

\section{Equation}

\section{Combination method}

FAO 56-PM

$$
\text { ETo }=\frac{0.408 \Delta\left(R_{n}-G\right)+\gamma \frac{900}{\left(T_{\text {mean }}+273\right)} u_{2}\left(e_{s}-e_{a}\right)}{\Delta+\gamma \cdot\left(1+0.34 . U_{2}\right)}
$$

\section{Temperature methods}

\begin{aligned} \hline BC & $E T o=a+b_{B} * P(0.46 T+8.13) \\ & a=0.0043 \quad . R H_{\text {min }}-n / N-1.41\end{aligned}$

TURC if $\mathrm{RH}>50 \%$

if $\mathrm{RH}<50 \%$

$$
\text { ETo }=0.013 \frac{T_{\text {mean }}}{\left(T_{\text {mean }}+15\right)}\left(R_{s}+50\right)
$$

$$
\text { ETo }=0.013 \frac{T_{\text {mean }}}{\left(T_{\text {mean }}+15\right)}\left(R_{s}+50\right)\left(1+\frac{(50-R H)}{70}\right)
$$

JH

$$
\text { ETo }=C_{T}\left(T-T_{X}\right) R_{S}
$$

HG

$$
E T o=0.0023 R_{A} \sqrt{T D}\left(T_{\text {mean }}+17.8\right)
$$

\begin{tabular}{lc}
\hline & Radiation met \\
\hline FAO-Rad & $E T o=a+b\left(\frac{\Delta}{\Delta+\gamma} R_{s}\right)$
\end{tabular}

PT

$$
\text { ETo }=\alpha \frac{1}{\lambda} \frac{\Delta}{(\Delta+\gamma)}\left(R_{n}-G\right)
$$

$\mathbf{T}_{\text {max }}:$ maximum air temperature.

RH: relative humidity.

$\mathbf{U}_{2}$ : wind speed.

$\mathbf{R}_{\mathbf{n}}$ : net radiation.

n: actuel Daily Sunshine duration (hours).

$\mathbf{e}_{\mathrm{s}}$ : saturation vapor pressure $(\mathrm{kPa})$.

$\mathbf{e}_{\mathbf{s}}-\mathbf{e}_{\mathbf{a}}$ : saturation vapour pressure deficit $[\mathrm{kPa}]$.

$\Delta$ : slope vapour pressure curve $\left[\mathrm{kPa}^{\circ} \mathrm{C}^{-1}\right]$.
$\mathbf{T}_{\min }$ : minimum air temperature.

$\mathbf{R H}_{\text {min }}$ : minimum relative humidity.

$\mathbf{R}_{\mathbf{s}}$ : solar radiation.

$\mathbf{N}$ : maximum possible daily sunshine hours. $\mathbf{e}_{\mathbf{a}}$ : actual vapor pressure.

G: soil heat flux density ( $\mathrm{MH} / \mathrm{m}^{2}$ per day). $\gamma$ : psychrometric constant $\left[\mathrm{kPa}{ }^{\circ} \mathrm{C}-1\right]$. 


\section{c) Statistical analysis:}

In order to evaluate ETo values using the different methods in comparison with FAO P-M method. Data of all methods were tested on basis of the following statistical parameters (El-Mageed, T.A.A. and ElWahed, M.A., 2014):

\section{Percentage error of estimates (PE)}

PE calculated by the following equation:

$$
P E=\frac{E T o \text { values calculated by different methods }}{E T o \text { value calculated by P-M method }}
$$

\section{The root-mean-square difference (RMSD)}

To evaluate The RMSD criterion was used to compare the estimated ETo values by different methods and P-M ETo method. The RMSD was selected as an appropriate ranking criterion because of the fact that this statistical parameter indicates the ability of equations and adjusted equations to accurately estimate reference evapotranspiration during all months (Trajkovic and Kolakovic, 2009).

$$
R M S D=\left[\frac{\sum_{i=1}^{n}\left[\text { PM }(E T o)-E T o_{\text {estimated }}\right]^{2}}{n}\right]^{0.5}
$$

where $\mathrm{n}=$ total number of observations.

\section{Mean bias error (MBE)}

$$
\boldsymbol{M B E}=\frac{\sum_{i=1}^{n}\left[P M(E T o)-E T o_{\text {estimated }}\right]}{n}
$$

According to these statistical parameters, the criteria used to select the best method is to have the smallest absolute deviation value. The criteria applied to select the more suitable method was associated with the smallest absolute deviation value obtained.

\section{d) GIS application:}

\section{Elevation Data}

The digital elevation model (DEM) used in this study is the SRTM (NGA SRTM "finished" $3 \operatorname{arcsec}$ ) data, which was retrieved freely from https://lpdaac.usgs.gov. Then, it was clipped to the boundary of the study area.

\section{Geostatistical analysis}

Kriging analysis was applied to generate the ETo maps of the study area. Where the point map of the stations was utilized in geostatistical analysis 
to generate spatial distribution maps of ETo. Where one map was generated to represent the ETo values of the P-M method. On the other hand, the estimated ETo values for each station based on the relevant best-method were used to generate ETo map for the study area.

\section{RESULTS AND DISCUSSIONS}

\section{Evaluation of estimation methods}

For the studied stations, the monthly ETo values were estimated using the tested seven equations. Then, the obtained values from the six simple ETo method were compared with that values of P-M method. The calculated statistical parameters i.e., PE, MBE and RMSD for all methods in each station as compared to the PM method are given in Table (3).

Table 3. Summary statistics of PE, MBE and RMSD and best ETo estimation method for the studied locations

\begin{tabular}{|c|c|c|c|c|c|c|}
\hline \multirow[b]{2}{*}{ Station } & \multicolumn{6}{|c|}{ Best method: } \\
\hline & $\begin{array}{c}\text { Based on } \\
\text { PE }\end{array}$ & PE & $\begin{array}{c}\text { Based on } \\
\text { RMSD }\end{array}$ & RMSD & $\begin{array}{c}\text { Based on } \\
\text { MBE }\end{array}$ & MBE \\
\hline Nalut & Turc & 1 & $\mathrm{BC}$ & 0.46 & Turc & 0.02 \\
\hline Zoara & Turc & 1.01 & $\mathrm{HG}$ & 0.20 & Turc & -0.05 \\
\hline Tripoli & $\mathrm{HG}$ & 1.01 & Turc & 0.42 & $\mathrm{HG}$ & -0.05 \\
\hline Mosrata & PT & 0.98 & Turc & 0.21 & PT & 0.07 \\
\hline Sirt & Turc & 1.01 & Turc & 0.22 & Turc & -0.03 \\
\hline Shahat & Turc & 1.01 & Turc & 0.07 & Turc & -0.01 \\
\hline Derna & PT & 0.99 & Turc & 0.35 & PT & 0.04 \\
\hline Tubruk & Turc & 1.02 & Turc & 0.21 & Turc & -0.09 \\
\hline Ghadames & $\mathrm{BC}$ & 1.02 & $\mathrm{BC}$ & 0.41 & $\mathrm{BC}$ & -0.10 \\
\hline Sebha & FAO-Rad & 1 & FAO-Rad & 0.33 & FAO-Rad & 0.02 \\
\hline Hon & Turc & 1.01 & Turc & 0.45 & Turc & -0.05 \\
\hline Galo & Turc & 1.02 & Turc & 0.49 & Turc & -0.11 \\
\hline Gagbub & $\mathrm{BC}$ & 1 & $\mathrm{HG}$ & 0.20 & $\mathrm{BC}$ & 0.00 \\
\hline Opari & HG & 1.07 & $\mathrm{HG}$ & 0.37 & HG & -0.35 \\
\hline Ghat & Turc & 1.05 & Turc & 0.60 & $\mathrm{JH}$ & 0.16 \\
\hline Tazirbu & $\mathrm{HG}$ & 1.1 & $\mathrm{HG}$ & 0.49 & $\mathrm{HG}$ & -0.48 \\
\hline Kufra & $\mathrm{BC}$ & 1.03 & FAO-Rad & 0.45 & $\mathrm{BC}$ & -0.21 \\
\hline
\end{tabular}

As shown in Table (3), most of the best methods exceeded ETo values estimated by the P-M method. The overview of all results revealed that the Turc and B-C methods perform better among the stations. The 
selection of the best method was done according to the values of PE, MBE and RMSD statistical parameters. Thus, for each station, the method having best values in two or three statistical parameters were assigned as the best method. Furthermore, generally, the study area could be divided into two zones; Northern and Southern ones, Figure (3).

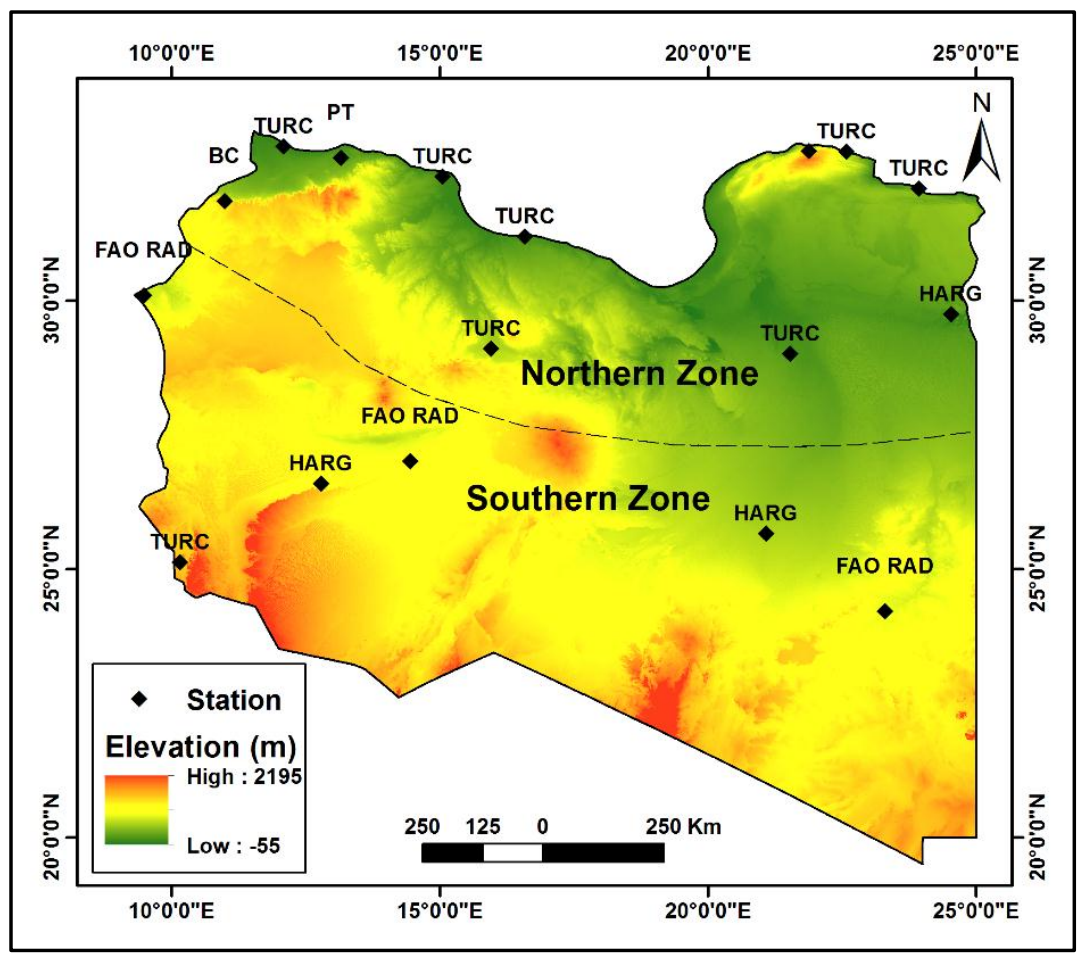

Fig. (3): ETo zones and the best ETo methods overlaid on DEM of the study area.

(A) Northern zone: which extended from the coastal line towards south including the following locations: Nalut, Zuara, Mosrata, Sirt, Shahat, Derna, Tubruk, Hon, Galo and Gagbub where the best method was Turc, while for Tripoli the best method was HG.

(B) Southern zone: as for Opari and Tazirbu, the best method was HG; BC for Kufra and Ghadames; FAO-Rad for Sebha; and JH for Ghat. The poor performance of the $\mathrm{J}-\mathrm{H}$ method obtained in this study is in a good agreement with the results found in Serbia (Trajkovic and Kolakovic 2009), Florida (Irmak et al. 2003a, b) and Iran (Tabari et al. 2011). 


\section{ETo Mapping:}

Values of evapotranspiration estimated by the P-M method and by the best method for each station were interpolated using ordinary kriging to generate ETo maps of the study area, Figure (4). As shown in Figure (4a), the ETo value ranges from 3.4 to $7.1\left(\mathrm{~mm} \mathrm{day}^{-1}\right)$, while in case of the best methods (Figure 4b) ETo ranges between 3.4 and 7.4 (mm day ${ }^{1}$ ), and generally, ETo value increases from north to south. This could be resulted as the distribution of mean air-temperature that also increases towards south.

Moreover, the elevation of the study area, as shown in Figure (3), rises from north to south direction, which affects the distribution of climatic parameters, and consequently affects ETo values.

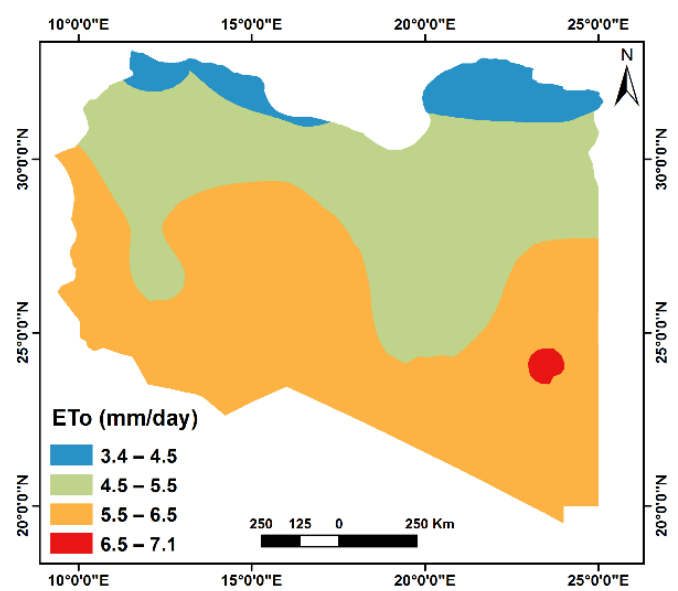

( a )

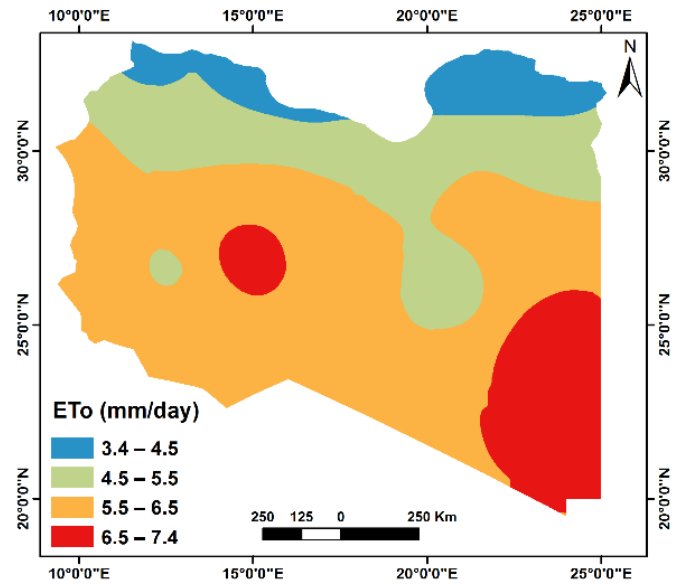

( B )

Fig. (4): Spatial distribution of ETo $\left(\mathrm{mm} \mathrm{day}^{-1}\right)$ in the study area, a) using P-M method, and b) most reliable estimation method for each station.

\section{CONCLUSSION}

Seven methods were applied to estimate reference evapotranspiration using weather data from seventeen stations separated at whole Libya. The FAO P-M method was used as the standard of comparison for evaluating the other six methods for all stations. It was concluded that there are two regions of different climatological characteristics namely: Region (1): Nalut, Zuara, Mosrata, Sirt, Shahat, Derna, Tubruk, Hon, Galo and 
Gagbub where the most reliable method was Turc. Region (2): Opari and Tazirbu with HG as best method, BC for Kufra and Ghadames, FAO-Rad for Sebha; and JH for Ghat. Furthermore, the estimated ETo values by P$M$ method and by the best method for each location were interpolated to generate ETo maps of the study area which could be employed in various decisions at regional scale. Finally, realized ETo equations can be used according the meteorological data availability for each region.

\section{REFERENCES}

Abdelhadi, A. W., Hata, T., Tanakamaru, T. A., \& Tariq, M. A. (2000). Estimation of crop water requirements in arid region using PenmanMonteith equation with derived crop coefficients: A case study on Acala cotton in Sudan Gezira irrigated scheme. Agric Water Manage, 45, 203-214.

Alexandris, S., P. Kerkides, and A. Liakatas. (2006). Daily reference evapotranspiration estimates by the "Copais" approach. Agric Water Manage, 82.3 371-386.

Allen RG, Pereira LS, Raes D, Smith M. (1998). Crop Evapotranspiration: Guidelines for Computing Crop Requirements, Irrigation and Drainage Paper 56. FAO: Roma, Italia.

Allen, R.G., Clemmens, A.J., Burt, C.M., Solomon, K., O'Halloran, T. (2005). Prediction accuracy for project-wide evapotranspiration using crop coefficients and reference evapotranspiration. Journal of Irrigation and Drainage Engineering. 131(1):24-36.

Droogers, P., \& Allen, R. G. (2002). Estimating reference evapotranspiration under inaccurate data conditions. Irrigation and Drainage Systems 16, 33-45.

Du, T., Kang, S., Sun, J., Zhang, X., \& Zhang, J. (2010). An improved water use efficiency of cereals under temporal and spatial deficit irrigation in north China. Agricultural Water Management, 97(1), 66-74.

El-Mageed, T.A.A. and El-Wahed, M.A. (2014). Assessment of several reference evapotranspiration estimation methods under coastal Mediterranean conditions. Pothalla journal. Vol 44, No. 7, 169-182.

Gavilan, P., Lorite, I.J., Tornero, S., \& Berengena, J. (2006). Reginonal calibration of Hargreaves equation for estimation of reference ET in a semiarid environment. Agric. Water Manage., 81, 257-281. 
Hargreaves, G. H., Allen, R. G., (2003). History and evaluation of Hargreaves evapotranspiration equation. J. Irrig. Drain.Eng. 129, 53-63.

Hassanli, A. M., Ahmadirad, S., \& Beecham, S. (2010). Evaluation of the influence of irrigation methods and water quality on sugar beet yield and water use efficiency. Agric Water Manage., 97, 357-362

Jensen, M. E., Burman, R. D., \& Allen, R. G. (1990). Evapotranspiration and irrigation water requirements. ASCE Manuals and Reports on Engineering Practices No.70, Am. Soc. Civil Engrs., NY, U.S.A.:360 pp.

Landeras, G., Ortiz-Barredo, A., \& Lopez, J. (2008). Comparison of artificial neural network models and empirical and semi-empirical equations for daily reference evapotranspiration estimation in the Basque Country (Northern Spain). Agric Water Manage, 95, 553565.

Lopez-Urrea, R., de Santa Olalla, F. M., Fabeiro, C., \& Moratalla, A. (2006). An evaluation of two hourly reference evapotranspiration equations for semiarid conditions. Agric Water Manage, 86, 277282.

Maeda, Eduardo Eiji, David A. Wiberg, and Petri KE Pellikka. (2011). "Estimating reference evapotranspiration using remote sensing and empirical models in a region with limited ground data availability in Kenya". Applied Geography 31.1: 251-258.

Martinez, C. J., \& Thepadia, M. (2010). Estimating reference evapotranspiration with minimum data in Florida. J. Irrig. Drain. Eng., 136, 494-501.

Nandagiri, L., \& Kovoor, G. M. (2006). Performance evaluation of reference evapotranspiration equations across a range of Indian climates. J. Irrig. Drain. Eng., 132(3), 238-249.

Sentelhas, P. C., Gillespie, T. J., \& Santos, E. A. (2010). Evaluation of FAO Penman-simple climatic formula evolved up to date. Ann. Argon., 12, 13-14.

Tabari, H., Grismer, M. E., \& Trajkovic, S. (2011). Comparative analysis of 31 reference evapotranspiration methods under humid conditions. Irrig Sci. DOI 10.1007/s00271- 011-0295-z. 
Trajkovic, S. and Kolakovic, S. (2009). Evaluation of reference evapotranspiration equations under humid conditions. Water Resources Management, 23(14), p.3057.

\section{الملخص العربي}

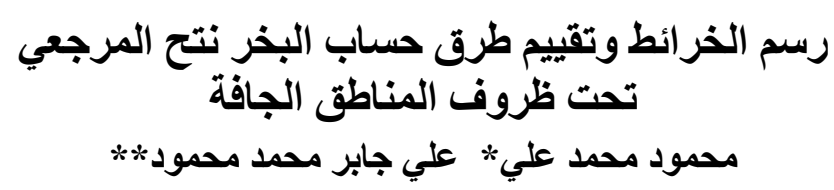

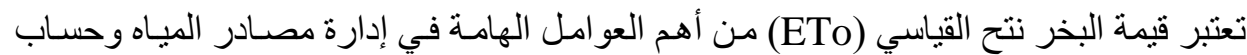

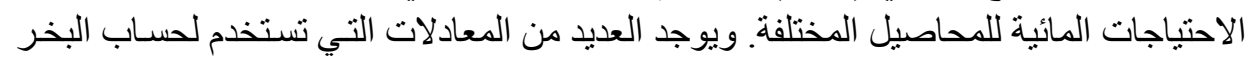

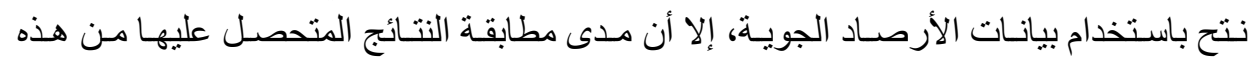

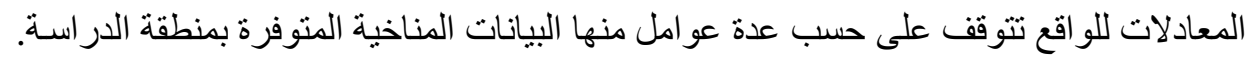

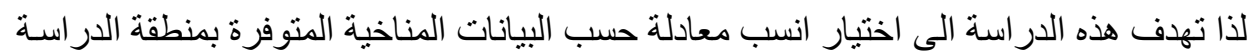

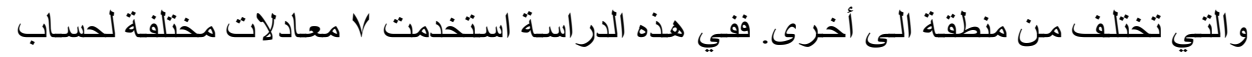

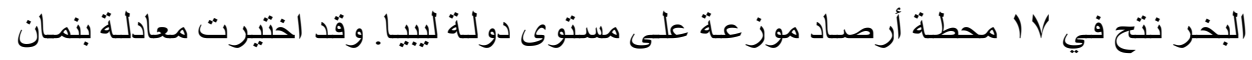

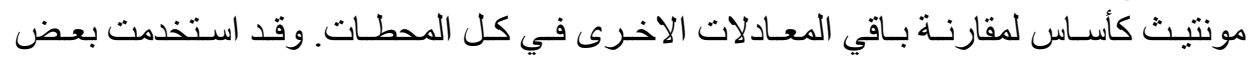

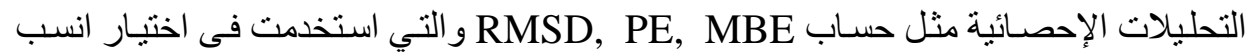

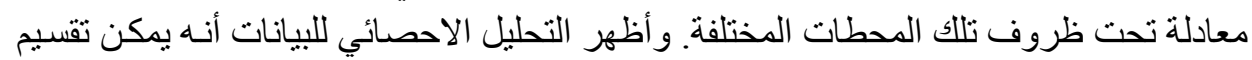
المحطات في منطقة الدر اسة الى منطقتين هما:

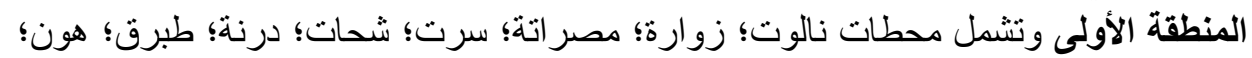
جالو وجغبوب حيث كان انسب معادلة هي ترك ونك

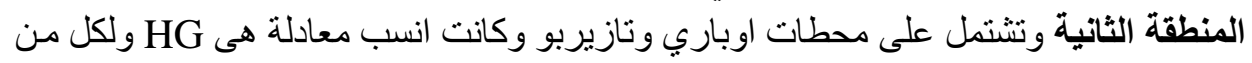
كفرة و غدامس كانت معادلة BC أما محطة سبها كانت

وقد استخدمت القيم المحسوبة للبخر نتح القياسي سواء بطرية بنمان مونتيث أو باستخدام أفضل

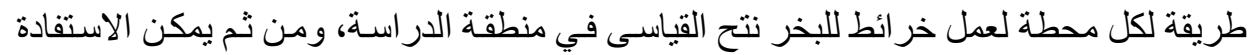

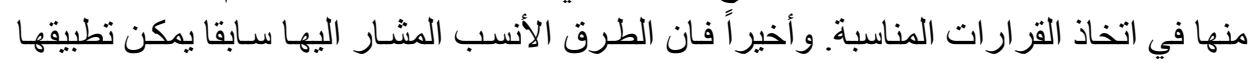
تبعا لمدى تو افر البيانات المناخية. 